\title{
The effectiveness of Saccharomyces cerevisiae in inhibiting aflatoxin production and reducing the harmful effects of aflatoxin in ducklings
}

\author{
Hai N. Nguyen ${ }^{1 *}, \&$ Anh T. N. Le ${ }^{2}$
}

${ }^{1}$ Faculty of Animal Science and Veterinary Medicine, Nong Lam University, Ho Chi Minh City, Vietnam

${ }^{2}$ Sub-department of Animal Health, Dong Nai, Vietnam

ARTICLE INFO
Short communication
Received: January 13, 2021
Revised: February 02, 2021
Accepted: February 26, 2021
Keywords
Aflatoxin
Duck
Saccharomyces cerevisiae
${ }^{*}$ Corresponding author
Nguyen Ngoc Hai
Email: nguyenngochai@hcmuaf.edu.vn

\section{ABSTRACT}

Sacharomyces cerevisiae isolates were obtained from baker's yeast, soil, fruit and identified with PCR. Twenty seven isolates of $S$. cerevisiae were screened for capacity of inhibition of aflatoxin production of Aspergillus flavus (A. flavus) on coconut extract agar media (CEA). The results showed that the coculture method of $S$. cerevisiae isolates and aflatoxin producing A. flavus on CEA medium could be used for screening the strains that are able to antagonize aflatoxin-producing A. flavus. On ground corn medium, with the rate of $10^{4}$ aflatoxin-producing A. flavus spores and $10^{8}$ S. cerevisiae yeast cells/g, S. cerevisiae was able to reduce the amount of aflatoxin produced by $A$. flavus in corn. In an in vivo experiment, it was found that addition of $10^{8}$ cells of $S$. cerevisiae to one $\mathrm{kg}$ of duck feed contaminated with $300 \mathrm{ppb}$ aflatoxin from 1 to 10 days of age reduced adverse effects of aflatoxin on the liver and kidneys of ducks.

Cited as: Nguyen, H. N., \& Le, A. T. N. (2021). The effectiveness of Saccharomyces cerevisiae in inhibiting aflatoxin production and reducing the harmful effects of aflatoxin in ducklings. The Journal of Agriculture and Development 20(1), 24-30. 


\title{
Hiệu quả của Saccharomyces cerevisiae trong việc ức chế sản sinh aflatoxin và làm giảm tác hại của aflatoxin ở vịt con
}

\author{
Nguyễn Ngọc Hải ${ }^{1 *}$ \& Lê Thị Ngọc Ánh ${ }^{2}$ \\ ${ }^{1}$ Khoa Chăn Nuôi Thú Y, Trường Đại Học Nông Lâm TP.HCM, TP. Hồ Chí Minh \\ ${ }^{2}$ Chi Cục Thú Y Tỉnh Đồng Nai, Đồng Nai
}

\author{
THÔNG TIN BÀI BÁO \\ Bài báo khoa học (ngắn) \\ Ngày nhận: 13/01/2021 \\ Ngày chỉnh sửa: $02 / 02 / 2021$ \\ Ngày chấp nhận: 26/02/2021

\section{Từ khóa} \\ Aflatoxin \\ Saccharomyces cerevisiae \\ Vịt con \\ *Tác giả liên hệ \\ Nguyễn Ngọc Hải \\ Email: nguyenngochai@hcmuaf.edu.vn
}

\section{TÓM TẮT}

Từ các nguồn men bánh mì, đất, trái cây, 27 gốc nấm men Saccharomyces cerevisiae đã được thu nhận thông qua phân lập và định danh bằng kỹ thuật $\mathrm{PCR}$. Định tính khả năn ức chế của các gốc $S$. cerevisiae phân lập được đối với sự sản sinh aflatoxin từ Aspergillus flavus trên môi trường nước cốt dừa. Kết quả ghi nhận phương pháp định tính trên môi trường nước cốt dừa có thể sử dụng làm phương pháp sàng lọc sơ bộ chủng $S$. cerevisiae có tác động ức chế đối với nấm mốc $A$. flavus sinh aflatoxin. Trên môi trường bắp xay, với tỷ lệ $10^{4}$ bào tử nấm mốc $A$. flavus sinh aflatoxin và $10^{8}$ tê̂ bào nấm men $S$. cerevisiae/g bắp cho thấy S. cerevisiae có khả năng làm giảm lượng aflatoxin do $A$. flavus sinh ra trong bắp. Trong thử nghiệm trên vịt con 1 ngày tuổi, với thức ăn hỗn hợp được gây nhiễm $300 \mathrm{ppb}$ aflatoxin và được trộn với $10^{8}$ tế bào $S$. cerevisiae $/ \mathrm{kg}$ thức ăn, đã làm giảm rõ rệt tác động của aflatoxin lên gan và thận của vịt con.

\section{1. Đặt Vấn Đề}

Aflatoxin là độc tố vi nấm được sản xuất chủ yếu bởi Aspergillus flavus (A. flavus) và $A s$ pergillus parasiticus ( $A$. parasiticus). Độc tố này gây độc cho gan dẫn đến ung thư và làm chậm sự phát triển của gia súc, gia cầm (Kusumaningtyas, 2006).

Việt Nam là một nước nhiệt đới, nóng ẩm rất thuận lợi cho sự phát triển của nấm mốc và sự sản sinh độc tố của nó. Một số phương pháp vật lý, hóa học và sinh học đã được áp dụng để giảm tác hại của aflatoxin trong thực phẩm và thức ăn gia súc. Trong đó, kiểm soát sinh học đã là một phương pháp đầy hứa hẹn để loại bỏ aflatoxin trong thực phẩm và thức ăn chăn nuôi (Kim, 2007). Ngoài B. subtilis đã được xác định có thể ức chế sự sản sinh aflatoxin của $A$. flavus (Nguyen, 2006), S. cerevisiae cũng là một vi sinh vật tiềm năng trong xử lý sinh học và làm giảm thiểu độc tính của aflatoxin đối với vật nuôi. Stanley \& ctv. (2010), Khadem \& ctv. (2012) và Pizzolitto \& ctv. (2013) đã ghi nhận hiệu quả tốt của $S$. cerevisiae trong việc làm giảm độc tính của aflatoxin ở trên gà. Ngoài khả năng làm giảm độc tính của aflatoxin, $S$. cerevisiae còn là nguồn dinh dưỡng và chất kích thích miễn dịch không đặc hiệu đối với gia cầm. Vì thế, $S$. cerevisiae là một đối tượng nghiên cứu tiềm năng trong mục đích vừa làm giảm tác hại của aflatoxin vừa hỗ trợ tăng trưởng và sức đề kháng ở vật nuôi.

Nghiên cứu đã được tiến hành nhằm mục tiêu sàng lọc nhanh các phân lập $S$. cerevisiae có khả năng ức chế sản sinh aflatoxin của $A$. flavus và đánh giá hiệu quả của các phân lập này trong việc làm giảm độc tính aflatoxin trên gan và thận của 
vịt con 1 ngày tuổi được cho ăn thức ăn công nghiệp có bổ sung thêm độc tố aflatoxin.

\section{Vật Liệu Và Phương Pháp Nghiên Cứu}

\subsection{Vật liệu}

Nghiên cứu được thực hiện tại phòng thí nghiệm vi sinh, Bộ môn Bệnh Truyền nhiễm và Thú y Cộng đồng, Khoa Chăn nuôi Thú y, Trường Đại học Nông Lâm TP.HCM.

Chủng nấm mốc A. flavus (Bộ môn Bệnh Truyền nhiễm và Thú $\mathrm{y}$ Cộng đồng, Khoa Chăn nuôi Thú y, Trường Đại học Nông Lâm TP.HCM).

Thức ăn hỗn hợp dạng bột được mua săn trên thị trường của công ty thức ăn chăn nuôi VINA được xét nghiệm âm tính với aflatoxin.

Vịt 1 ngày tuổi, không phân biệt trống mái, được mua của Trại giống VIGOVA - Phân Viện Chăn nuôi Nam Bộ tại xã Bình Minh, huyện Trảng Bom, tỉnh Đồng Nai.

PCR với bộ kit GoTaq Green Master Mix (Promega, Mỹ).

Aflatoxin B1 tinh khiết (Sigma, Mỹ).

\subsection{Phương pháp nghiên cứu}

\subsubsection{Phân lập và giám định $S$. cerevisiae}

Mẫu đất, men bánh mì được phân lập trên đĩa thạch Sabouraud agar (SA) có bổ sung kháng sinh chloramphenicol $(50 \mathrm{mg} / \mathrm{mL})$, ủ ở nhiệt độ phòng trong 24 giờ.

Những khuẩn lạc nghi ngờ là $S$. cerevisiae được nhuộm đơn và quan sát dưới kính hiển vi, giữ lại những gốc phân lập có đặc điểm phù hợp của tế bào nấm men $S$. cerevisiae, giữ giống trên môi trường thạch nghiêng $\mathrm{SA}$ và định danh bằng phương pháp PCR.

Phương pháp PCR được tiến hành theo mô tả của Sabaté \& ctv. (2000), với cặp mồi Sc1 5' AACGGTGAGAGATTTCTGTGC - 3' và Sc2 5' - AGCTGGCAGTATTCCCACAG - 3'. Độ dài đoạn $\mathrm{ADN}$ được nhân lên là 1.170 bp. Thông số chu kỳ nhiệt của giai đoạn biến tính ban đầu là $94^{\circ} \mathrm{C}$ trong vòng 10 phút, tiếp theo là 35 chu kỳ với bước biến tính $94^{\circ} \mathrm{C}$ trong 30 giây, bắt cặp ơ $50^{\circ} \mathrm{C}$ trong 30 giây và kéo dài ở $72^{\circ} \mathrm{C}$ trong 1 phút. Kết thúc phản ứng ở $72^{\circ} \mathrm{C}$ trong 10 phút và giữ ở $4^{\circ} \mathrm{C}$. Sản phẩm PCR được đem giải trình tự và so sánh với bộ gen của nấm men $S$. cerevisiae trên Genbank để khẳng định $S$. cerevisiae.

2.2.2. Khảo sát định tính khả năng ức chế $A$. flavus sản sinh aflatoxin của những gốc $S$. cerevisiae phân lập được

Phương pháp kiểm tra được thực hiện phỏng theo mô tả của Nguyen (2006). Cấy gốc S. cerevisiae phân lập lên đĩa môi trường thạch nước cốt dừa (mỗi đĩa $20 \mathrm{~mL}$ môi trường), mỗi đĩa từ 3 đến 4 gốc nấm men. Ủ ở nhiệt độ phòng trong 2 ngày, sau đó cấy $A$. flavus vào giữa đĩa môi trường đã có cấy các gốc $S$. cerevisiae, tiếp tục ủ ở nhiệt độ phòng trong 3 ngày.

Sau 3 ngày, soi đĩa dưới ánh đèn UV (bước sóng $365 \mathrm{~nm}$ ) để theo dõi màu huỳnh quang xung quanh khuẩn lạc $A$. flavus. Đánh giá khả năng của các gốc $S$. cerevisiae phân lập ức chế A. flavus sản sinh aflatoxin qua độ phát sáng huỳnh quang xung quanh khuẩn lạc $A$. flavus. Màu huỳnh quang càng sáng ít ở đĩa cấy chủng nấm men nào thì chủng nấm men đó có khả năng ức chế $A$. flavus sản sinh aflatoxin càng mạnh. Sau đó chọn ra chủng nấm men có khả năng ức chế $A$. flavus sản sinh aflatoxin mạnh để tiến hành thí nghiệm định lượng tiếp theo.

2.2.3. Khảo sát định lượng khả năng ức chế $A$. flavus sản sinh aflatoxin của những gốc $S$. cerevisiae phân lập được

Thí nghiệm được thực hiện trên môi trường bắp xay nhỏ, kích thước khoảng $2-3 \mathrm{~mm}$, sau đó bắp xay được hấp tiệt trùng ở $121^{\circ} \mathrm{C}$ trong 15 phút. Chọn gốc $S$. cerevisiae thể hiện tốt nhất khả năng ức chế aflatoxin tốt nhất ở thí nghiệm định tính (2.2.2) để thực hiện thí nghiệm định lượng trên môi trường bắp xay. Nuôi cấy chung tế bào nấm men và bào tử nấm $A$. flavus trên môi trướng nguyên liệu bắp trong các chai thể tích 0,5 L. Mỗi lô thí nghiệm có 3 chai. Mỗi chai có $50 \mathrm{~g}$ bắp xay, ẩm độ của bắp được hiệu chỉnh với nước cất vô trùng có chứa bào tử nấm mốc và tế bào nấm men theo nồng độ đã xác định và chuẩn bị trước, để đạt ẩm độ khoảng $30 \%$. Tỉ lệ nuôi cấy bào tử nấm mốc và tế bào nấm men tương ứng là $10^{4} / 10^{8} / \mathrm{g}$. Riêng lô đối chứng 1 chỉ có bắp, không có nấm men và bào tử nấm mốc. Lô đối chứng 2 chỉ có $10^{4}$ bào tử $A$. flavus, không có nấm men. Bào tử nấm mốc và tế bào nấm men được chuẩn bị dạng huyền phù, đếm số lượng theo phương pháp đếm trên thạch đĩa, sau đó pha thành huyễn dịch có nồng độ tương ứng 
$10^{4} / \mathrm{mL}$ đối với bào tử nấm mốc và $10^{8} / \mathrm{mL}$ đối với tế bào nấm men.

Đặt các chai có bắp thí nghiệm ở nhiệt độ phòng. Sau 5 ngày chọn mẫu ngẫu nhiên 2 trong 3 chai của mỗi lô thí nghiệm để gửi đi phân tích hàm lượng aflatoxin trong bắp thí nghiệm bằng phương pháp sắc ký lỏng hiệu năng cao theo AOAC 990.33 - 2002 tại Trung tâm Dịch vụ Phân tích Thí nghiệm Thành phố Hồ Chí Minh.

\subsubsection{Xác định hiệu quả ức chế của $S$. cerevisiae đối với tác động của aflatoxin trên vịt}

Thí nghiệm gồm 2 đợt, mỗi đợt có 75 con, chia thành 3 lô $(25$ con/lô), được bố trí và cho ăn khẩu phần tương ứng như Bảng 1. Vịt được nuôi trong chuồng lồng bằng inox, mỗi ô có kích thước $0,6 \mathrm{~m}$ x $0,5 \mathrm{~m}$ x $0,5 \mathrm{~m}$, chăm sóc như nhau và theo dõi hàng ngày về tình trạng sức khỏe, theo dõi trong vòng 10 ngày tại Bộ môn Bệnh Truyền nhiễm và Thú y cộng đồng, Khoa Chăn nuôi - Thú $\mathrm{y}$, Trường Đại học Nông Lâm TP.HCM. Thức ăn được gửi đi xét nghiệm âm tính với aflatoxin trước khi bổ sung aflatoxin cho vịt ăn. Aflatoxin tinh khiết được pha theo hướng dẫn của nhà sản xuất (Sigma) và được bổ sung vào theo tỷ lệ để đạt mức dự kiến 300 ppb trong bắp cho vịt ăn.

Tiến hành cho điểm bệnh tích gan theo phương pháp được mô tả bởi Le (2002) và có sửa đổi từ thang chấm điểm dấu $(-,+,++,+++,+++)$ sang thang điểm số $(0,1,2,3$ và 4$)$ : $(0)$ : không có bệnh tích, (1): bệnh tích nhẹ, (2): bệnh tích trung bình, (3): bệnh tích nặng, (4): bệnh tích rất nặng. Tính bệnh tích điểm trung bình cho từng loại mẫu, theo từng lô.

Cho vịt ăn thức ăn bổ sung 300 ppb aflatoxin trong vòng 10 ngày. Kết thúc thí nghiệm chọn ngẫu nhiên 2 con/lô mổ khám lấy mẫu khảo sát bệnh tích vi thể gan, thận. Mẫu gan, thận được ngâm vào formol $10 \%$ và gửi làm tiêu bản vi thể tại Trung tâm Chuẩn đoán Xét nghiệm Bệnh Động vật thuộc Cơ quan Thú y vùng VI, đọc kêt quả tại Bệnh viện Thú $Y$, Trường Đại học Nông Lâm TP.HCM.

\section{Kết Quả và Thảo Luận}

\subsection{Phân lập và định danh $S$. cerevisiae}

Phản ứng PCR đã được thực hiện với 33 gốc nghi ngờ $S$. cerevisiae, xác định được $27 / 33$ gốc là nấm men $S$. cerevisiae. Kết quả chạy điện di

www.jad.hcmuaf.edu.vn sản phẩm PCR định danh $S$. cerevisiae được thể hiện qua Hình 1.

Trình tự nucleotide của sản phẩm PCR được so sánh với trình tự gốc của $S$. cerevisiae trên genbank, kết quả xác nhận các gốc nấm men thu được chính là $S$. cerevisiae. Những gốc nấm men $S$. cerevisiae sau đó được sử dụng trong thí nghiệm đánh giá định tính khả năng ức chế $A$. flavus sản sinh aflatoxin.

3.2. Xác định định tính khả năng ức chế $A$. flavus sản sinh aflatoxin của $S$. cerevisiae

Nuôi cấy chung $A$. flavus và các gốc nấm men phân lập được trên môi trường thạch nước cốt dừa. Sau 3 ngày nuôi cấy, tại nơi tiếp giáp giữa $A$. flavus và $S$. cerevisiae, bề mặt khuẩn lạc $A$. flavus bị lõm vào. Dưới ánh đèn cực tím ở bước sóng 365 nm, tại vị trí tiếp giáp, vòng sáng aflatoxin bị mờ và khuyết đi (Hình 2). Điều này chứng tỏ những chủng $S$. cerevisiae này có khả năng đối kháng với nấm mốc $A$. flavus và ức chế sự sản sinh aflatoxin của nấm mốc $A$. flavus.

\subsection{Khả năng ức chế A. flavus sản sinh afla- toxin của $S$. cerevisiae trên môi trường bắp xay vỡ}

Gốc S. cerevisiae số 96 có khả năng ức chế aflatoxin tốt nhất ở thí nghiệm định tính trên nước cốt dừa được chọn để tiến hành thí nghiệm định lượng trên môi trường bắp xay. Sau 5 ngày nuôi cấy chung tế bào nấm men và bào tử nấm mốc trong các chai. Mẫu thí nghiệm được phân tích hàm lượng aflatoxin, kết quả được trình bày ở Bảng 2.

Qua Bảng 2 ta thấy gốc $S$. cerevisiae số 96 , ở tỷ lệ nấm mốc/tế bào tương ứng là 104/108, trên môi trường bắp xay vỡ, ẩm độ $30 \%$, đã làm giảm hàm lượng aflatoxin khoảng 8 lần so với lô đối chứng chỉ nuôi cấy $A$. flavus. Như vậy, gốc S. cerevisiae phân lập được có khả năng ức chế sản sinh aflatoxin của $A$. flavus. Có thể mannanoligosaccharide (MOS) trong vách tế bào của nấm men hoặc sự hình thành các liên kết hydro và các tương tác giữa aflatoxin $\mathrm{B} 1$ và beta $\mathrm{D}$ - glucans trên thành tế bào nấm men đã làm giảm aflatoxin có trong bắp. Nghiên cứu của Zaghini \& ctv. (2005) ghi nhận, MOS có khả năng hấp phụ, làm giảm tác động của aflatoxin trên năng suất trứng khi được bổ sung vào trong thức ăn có nhiễm aflatoxin ở gà đẻ. Kusumaningtyas \& ctv. (2006) cũng đã ghi nhận khả năng của $S$. 
Bảng 1. Bố trí thí nghiệm hiệu quả của $S$. cerevisiae đối với tác động của aflatoxin trên vịt

\begin{tabular}{ccl}
\hline Lô & Số vịt/lô (con) & Nghiệm thức \\
\hline 1 & 25 & Thức ăn hỗn hợp $(0 \mathrm{ppb}$ aflatoxin $)$ \\
2 & 25 & Thức ăn hỗn hợp + bắp nhiễm aflatoxin $(300 \mathrm{ppb})$ \\
3 & 25 & $\begin{array}{l}\text { Thức ăn hỗn hợp }+ \text { bắp nhiễm aflatoxin }(300 \mathrm{ppb})+10^{8} \text { tế bào S. cere- } \\
\text { visiae } / \mathrm{kg} \text { thức ăn }\end{array}$ \\
\hline
\end{tabular}

Bảng 2. Kết quả định lượng aflatoxin trên bắp xay khi nuôi cấy chung $S$. cerevisiae và A. flavus sinh aflatoxin

\begin{tabular}{cll}
\hline STT & Lô & Hàm lượng aflatoxin $(\mathrm{ppb})(\mathrm{n}=2)$ \\
\hline 1 & Đối chứng 1 & $0,895 \pm 0,055$ \\
2 & Đối chứng 2 & $3837,4 \pm 187,80$ \\
3 & S. cerevisiae + A. flavus & $444,7 \pm 15,20$ \\
\hline
\end{tabular}
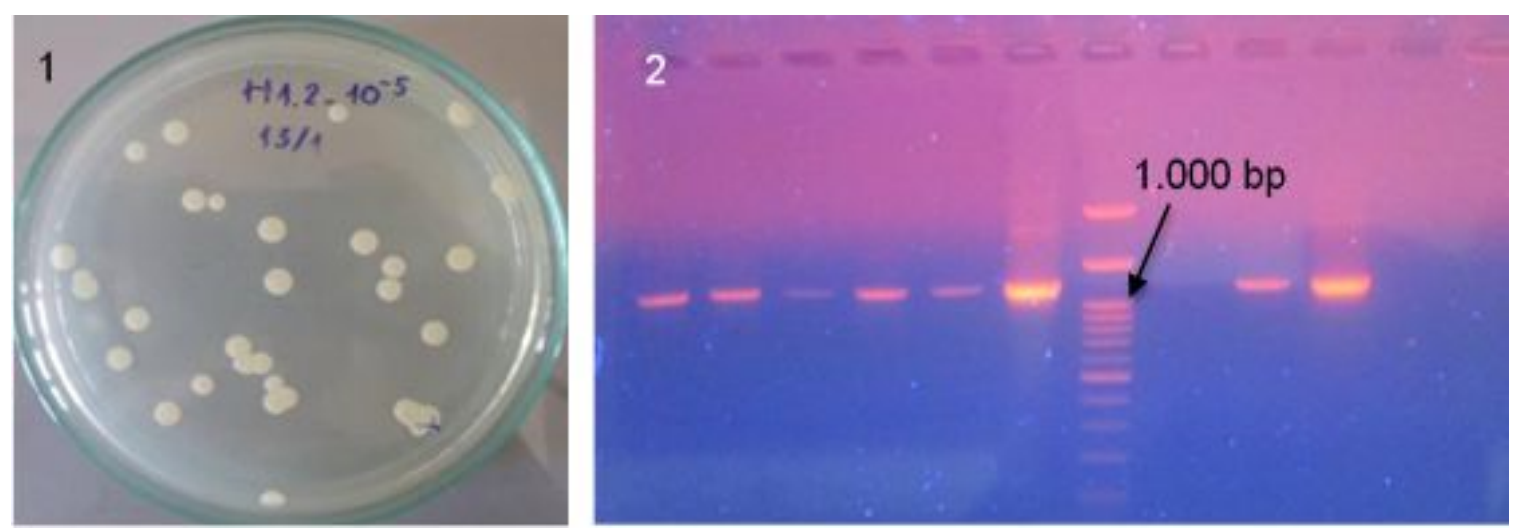

Hình 1. (1) Khuẩn lạc S. cerevisiae trên môi trường thạch Sabouraud 24 giờ nuôi cấy ở nhiệt độ phòng. (2) Điện di sản phẩm PCR định danh S. cerevisiae (đoạn ADN 1.170 bp).

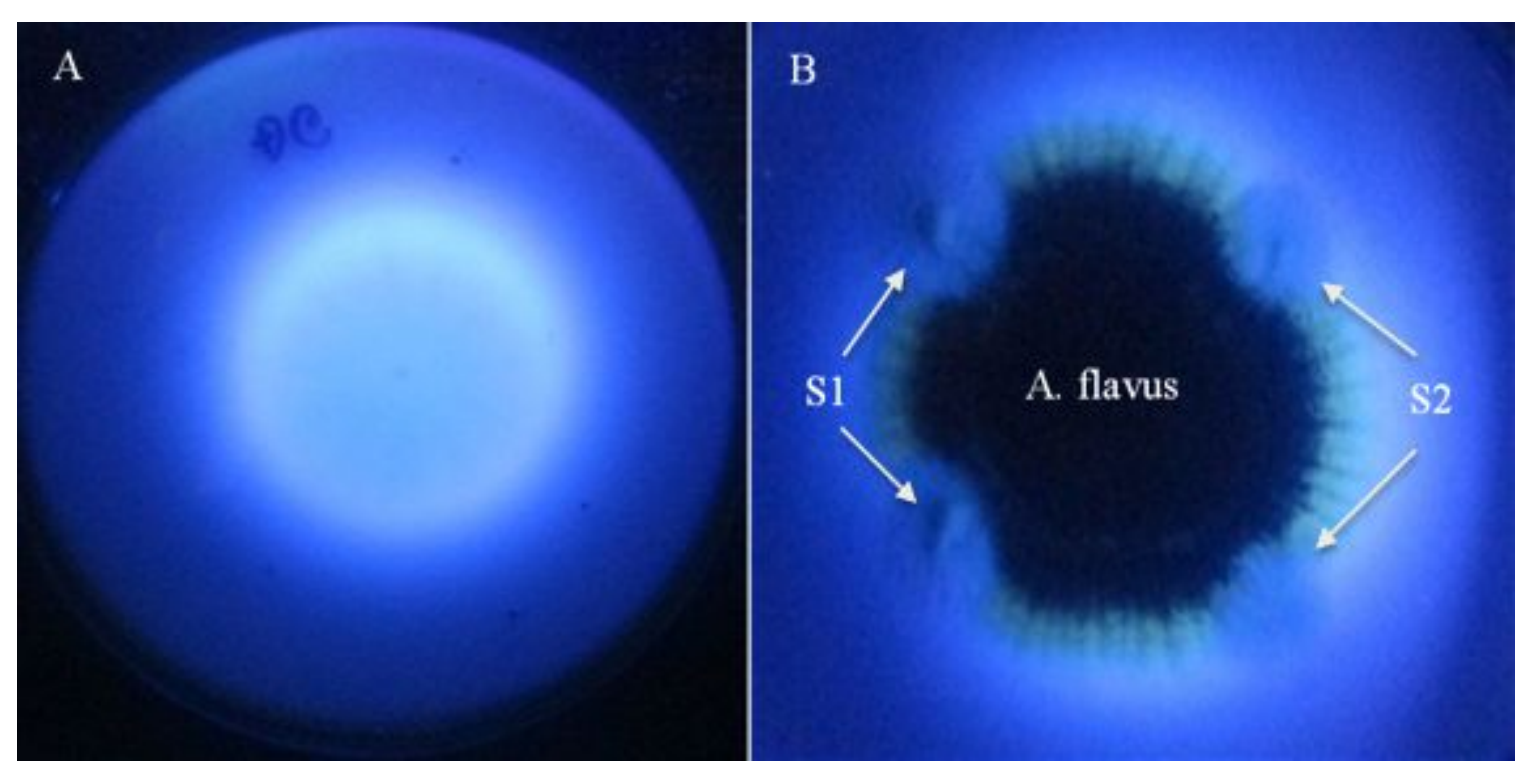

Hình 2. (A) Khuẩn lạc $A$. flavus (mặt dưới) trên môi trường thạch nước cốt dừa phát sáng dưới đèn UV. (B) A. flavus và $S$. cerevisae (chủng $\mathrm{S} 1, \mathrm{~S} 2$ ) nuôi cấy chung trên môi trường thạch nước cốt dừa. 
Bảng 3. Điểm trung bình bệnh tích vi thể trên gan của vịt thí nghiệm cho ăn thức ăn nhiễm afaltoxin có và không có bổ sung $S$. cerevisiae

\begin{tabular}{lccc}
\hline Bệnh tích & Lô $1(\mathrm{n}=6)$ & $\begin{array}{c}\text { Lô } 2-300 \mathrm{ppb} \text { aflatoxin } \\
(\mathrm{n}=6)\end{array}$ & $\begin{array}{c}\text { Lô 3 - 300 ppb aflatoxin } \\
+ \text { S. cerevisiae }(\mathrm{n}=6)\end{array}$ \\
\hline Thoái hóa mỡ & $0,5^{\mathrm{a}}$ & $3,5^{\mathrm{b}}$ & $2,0^{\mathrm{c}}$ \\
Tổn thương mô gan & - & 1,0 & - \\
Viêm gan & $0,5^{\mathrm{a}}$ & $3,0^{\mathrm{b}}$ & $1,0^{\mathrm{a}}$ \\
\hline
\end{tabular}

Ký hiệu $\mathrm{a}, \mathrm{b}, \mathrm{c}$ cùng hàng mô tả kết quả thống kê khác biệt có ý nghĩa với $P<0,05$ (Trắc nghiệm phi tham số Kruskal Wallis).

cerevisiae làm giảm aflatoxin $\mathrm{B} 1$ sau 5 ngày nuôi cấy $S$. cerevisiae trong thức ăn của gà bị nhiễm aflatoxin B1.

\subsection{Hiệu quả của $S$. cerevisiae đối với tác động của aflatoxin trên vịt}

Gan là cơ quan đích cho sự tác động của aflatoxin lên cơ thể sinh vật. Chính vì vậy, chỉ tiêu bệnh tích trên gan là một chỉ tiêu quan trọng trong đánh giá sự tác động của aflatoxin (Le, 2002). Mẫu gan của vịt con thí nghiệm được lấy ngẫu nhiên, cho điểm bệnh tích vi thể và tính điểm bệnh tích trung bình giữa các lô. Kết quả về bệnh tích vi thể trên gan của vịt được trình bày ở Bảng 3 .

Theo kết quả điểm bệnh tích vi thể ở Bảng 3 , nhận thấy tác động của aflatoxin lên gan của vịt là khá rõ ràng. Khi cho vịt ăn thức ăn chứa hàm lượng aflatoxin 300 ppb ở lô 2, gan của vịt bị tổn thương khá nặng, với mức độ thoái hóa mỡ nặng (điểm bệnh tích vi thể trung bình là 3,5 ), và viêm gan nặng với mức điểm là 3 . Trong khi đó, ở lô 1 , vịt chỉ ăn thức ăn hỗn hợp không có chứa aflatoxin, gan không có sự tổn thương mô gan, chỉ có thoái hóa mỡ nhẹ (điểm 0,5 ), và viêm gan nhẹ (điểm 0,5). Ở lô 3 , vịt được cho ăn thức ăn, tuy cũng chứa $300 \mathrm{ppb}$ độc tố aflatoxin, nhưng được bồ sung thêm $10^{8}$ tế bào $S$. cerevisiae $/ \mathrm{kg}$ thức ăn, mức độ bệnh tích nhẹ hơn hẳn so với lô 2 , với mức độ thoái hóa mỡ chỉ là 2 so với 3,5 ; đặc biệt mức độ viêm gan giảm rõ rệt, chỉ ở mức 1 so với mức 3 ở lô vịt ăn thức ăn nhiễm aflatoxin không được bổ sung $S$. cerevisiae. Như vậy, khi bổ sung $S$. cerevisiae vào thức ăn cho vịt đã làm giảm độc tính của aflatoxin lên gan, thể hiện qua hiệu quả làm giảm bệnh tích thoái hóa mỡ ở tế bào gan, viêm gan nhẹ hơn, cũng như không có sự tổn thương mô gan.

Thận là cơ quan đích thứ hai chịu sự tác động của aflatoxin ở vịt. Ở lô cho vịt ăn thức ăn có 300 ppb aflatoxin, bệnh tích vi thể ở thận khá rõ ràng với mô thận có nhiều vùng bạch cầu lympho, mô liên kết tạo thành những vùng viêm mãn, mô liên kết hóa sợi, có những cụm tế bào biến chất trên ống lượng. Trong khi đó, ở lô 1 , vịt chỉ ăn thức ăn hỗn hợp không có chứa aflatoxin, tế bào thận hoàn toàn bình thường, sung huyết rải rác. Ở lô 3 , với việc bổ sung $S$. cerevisiae trong thức ăn đã làm bệnh tích vi thể trên thận giảm xuống khá rõ, mức độ viêm giảm, thoái hóa ống mỡ ít hơn.

Theo Matur \& ctv. (2010), bổ sung chất chiết của $S$. cerevisiae đã làm giảm độc tính của aflatoxin đến hoạt động của tuyến tuỵ cũng như hoạt lực của chymotrypsin. Do vậy, chất chiết của $S$. cerevisiae có thể được sử dụng trong chăn nuôi nhằm làm giảm tác động có hại của aflatoxin trên gia cầm.

Stanley \& ctv. (1993) trong nghiên cứu của mình đã ghi nhận, bổ sung $1 \%$ S. cerevisiae vào trong khẩu phần làm giảm rõ rệt tác hại của aflatoxin trên gà thí nghiệm. Aflatoxin có khả năng làm giảm hoạt lực của các enzyme phân giải chất bột đường, đạm, chất béo, ảnh hưởng đến hoạt động biến dưỡng của gia cầm ăn thức ăn nhiễm aflatoxin. Trong khi đó, S. cerevisiae làm tăng tổng hợp một số enzymes quan trọng trong biến dưỡng của gia cầm như alanine transaminase, aspartate aminotransferase, lactate dehydrogenase, và creatine phosphokinase... nhờ đó làm giảm tác hại của aflatoxin. Không giống như hydrated sodium calcium aluminosilicate, có thể hấp phụ aflatoxin qua đó làm giảm tác động của độc tố này, $S$. cerevisiae làm giảm độc tính của aflatoxin nhờ vào khả năng tăng cường các enzyme chuyển hoá trong cơ thể (Stanley \& ctv.,1993).

Celýk \& ctv. (2003), đã ghi nhận với liều bổ sung $3,44 \times 10^{8}$ tế bào $S$. cerevisiae đã làm giảm bệnh tích viêm gan, thoái hoá mỡ và tổn thương mô gan, cũng như cải thiện tăng trưởng của gà giò khi cho ăn thức ăn nhiễm aflatoxin ở mức $200 \mathrm{ng} / \mathrm{g}$. Theo Pizzolitto \& ctv. (2013), khi bổ sung S. cerevisiae CECT 1891 với liều $5 \times 10^{9}$ tế bào/lít nước và $10^{10}$ tế bào/kg thức ăn đã ghi 
nhận hiệu quả làm giảm rõ rệt bệnh tích trên gan ở gà được cho ăn thức ăn nhiễm độc tố aflatoxin liều $1,2 \mathrm{ppm}$. Gan của gà ở nhóm ăn thức ăn nhiễm aflatoxin liều 1,2 ppm có màu nhạt và dễ nát hơn, trong khi đó gan của gà ở nhóm ăn thức ăn nhiễm aflatoxin và có bổ sung $S$. cerevisiae $\mathrm{CECT}$ có màu và độ chắc như gan bình thường. Tác giả đã kết luận rằng có thể sử dụng $S$. cerevisiae trong xử lý làm giảm độc tính của aflatoxin nhiễm trong thức ăn của gà. Tuy nhiên, hiệu quả của $S$. cerevisiae CECT 1891 đối với độc tính của aflatoxin thay đổi tuỳ theo cách thức sử dụng. Hiệu quả tốt nhất khi sử dụng $S$. cerevisiae CECT 1891 được pha trong nước uống.

Kết quả đánh giá bệnh tích gan vịt trong thí nghiệm ở Bảng 3 cho thấy, việc bổ sung $S$. cerevisiae trong thức ăn có tác dụng làm giảm độc tính của gan so với lô vịt đối chứng không được bổ sung $S$. cerevisiae. Tuy nhiên, mức độ thoái hoá mỡ ở gan vẫn còn ở mức 2 . Điều này có thể là do số lượng $S$. cerevisiae bổ sung trong thí nghiệm còn thấp và $S$. cerevisiae trong thí nghiệm này được cấp qua thức ăn. Ngoài ra, hiệu quả của các chế phẩm sinh học phụ thuộc nhiều vào khả năng hấp phụ độc tố aflatoxin của từng chủng sử dụng (Pinheiro \& ctv., 2020).

\section{Kết Luận}

Nhìn chung, nấm men $S$. cerevisiae có khả năng ức chế A. flavus sản sinh aflatoxin và làm giảm đáng kể độc tính của aflatoxin lên gan và thận của vịt con. Cần tiếp tục nghiên cứu đánh giá với hàm lượng aflatoxin cao hơn, liều và cách thức bổ sung $S$. cerevisiae cho vật nuôi và đánh giá thêm các khía cạnh tăng trưởng, miễn dịch để có kết luận đầy đủ hơn khả năng ứng dụng trong thực tế.

\section{Lời Cam Đoan}

Bài báo được công bố không có bất kỳ mâu thuẫn nào giữa các tác giả.

\section{Lời Cảm Ơn}

Nghiên cứu được thực hiện với kinh phí của Sở Khoa học và Công nghệ tỉnh Đồng Nai. Cảm ơn sự hỗ trợ của Vương Thị Hồng Vi, Võ Tấn Hùng và Dương Ngô Thị Bích Trâm, Phòng xét nghiệm chẩn đoán Thú y Hàn Việt, Trường Đại học Nông Lâm TP.HCM.

\section{Tài Liệu Tham Khảo (References)}

Çelýk, K., Denlý, M., \& Savas, T. (2003). Reduction of toxic effects of aflatoxin B1 by using baker yeast ( Saccharomyces cerevisiae) in growing broiler chicks diets. Revista Brasileira de Zootecnia 32(3), 615-619.

Kusumaningtyas, E., Widiastuti, R., \& Maryam R. (2006). Reduction of aflatoxin B1 in chicken feed by using Saccharomyces cerevisiae, Rhizopus oligosporus and their combination. Mycopathologia 162(4), 307311 .

Le, P. A. ( 2002). Effects of some substances capable of adsorbing Aflatoxin in super meat duck feeding diets (Unpublished Doctoral Dissertation). Nong Lam University, Ho Chi Minh City, Vietnam.

Nguyen, N. H. (2006). Bacillus subtilis possibly used for aflatoxin control. Proceedings of International workshop on Biotechnology in Agriculture (75-77). Ho Chi Minh City, Vietnam: Nong Lam University. 75-77.

Matur, E., Ergul, E., Akyazi, I., Eraslan. E., \& Cirakli, Z. T. (2010). The effects of Saccharomyces cerevisiae extract on the weight of some organs, liver, and pancreatic digestive enzyme activity in breeder hens fed diets contaminated with aflatoxins. Poultry Science 89, 2213-2220.

Pinheiro, R. E. E., Rodrigues, A. M. D., Lima, C. E., Santos, J. T. O., Pereyra, C. M., Torres, A. M., Cavaglieri, L. R., Lopes, J. B., \& Muratori, M. C. S. (2020). Saccharomyces cerevisiae as a probiotic agent and a possible aflatoxin B1 adsorbent in simulated fish intestinal tract conditions. Arquivo Brasileiro de Medicina Veterinária e Zootecnia 72(3), 862-870.

Pizzolitto, R. P., Armando, M. R., Salvano, M. A., Dalcero, A. M., \& Rosa, C. A. (2013). Evaluation of Saccharomyces cerevisiae as an antiaflatoxicogenic. Poultry Science 92, 1655-1663.

Sabaté, J., Guillamon, J. M., \& Cano, J. (2000). PCR differentiation of Saccharomyces cerevisiae from Saccharomyces bayanus/Saccharomyces pastorianus using specific primers. FEMS Microbiology Letters 193, 255-259.

Stanley, V. G., Ojo, R., Woldesenbet, S., Hutchinson, D. H., \& Kubena, L. F. (1993). The use of Saccharomyces cerevisiae to suppress the effects of aflatoxicosis in broiler chicks. Poultry Science 72, 1867-1872.

Zaghini, A., Martelli, G., Roncada, P., Simioli, M., \& Rizzi, L. (2005). Mannanoligosaccharides and aflatoxin B1 in feed for laying hens: Effects on egg quality, aflatoxins B1 and M1 residues in eggs, and aflatoxin B1 levels in liver. Poultry Science 84, 825-832. 